\title{
China-Pakistan Economic Corridor: Analvtical overview on Socio-Cultural Romance between China and Pakistan
}

DOI: https://doi.org/10.47175/rissj.v2i4.274

\section{| Muhammad Asif ${ }^{1,{ }^{*}}$ | Majid Ali ${ }^{2}$ | Abdoulaye M'Begniga ${ }^{3}$ | Zhou Guoqing ${ }^{4}$ | | Liu Yang ${ }^{5}$ | Muhammad Hashim ${ }^{6}$ |}

$1,4,5$ School of Journalism and Communication, Hunan Normal University, Changsha, China.

${ }^{2}$ Master in Civil and Commercial Law, School of Law, Anhui Normal University, Wuhu China.

${ }^{3}$ School of Literature, Anhui Normal University, Wuhu China.

${ }^{6}$ Assistant Professor School Management Sciences, National Textile University, Faisalabad, Pakistan

*asifanu@hotmail.com

\begin{abstract}
China Pakistan Economic Corridor (CPEC) is an important Belt and Road Initiative (BRI) project that integrates many countries. The CPEC project will play a vital role to make more strong relationship between China and Pakistan. CPEC project will enhance cooperation between Pakistan and China in field of socio-cultural and regional Bilateral Cooperation and exchange. Despite growth between two countries in the economic and trade field, there is a vital area to explore the cultural exchange, cooperation, and communication needed to improve from both sides. In this theoretical study method, the data has been obtained from primary and secondary sources. The primary sources consisted of books, official databases of China and Pakistan, MoU signed b/w both countries, etc., as the secondary sources consisted of research papers, newspapers, journals, online databases, etc. This paper has an analytical overview of the time value and general cultural and artistic exchanges between China and Pakistan. Further, the paper discussed the relationship between literature, art, and economics. In this paper, researchers have also examined the significant role of people-to-people contact for socio-cultural exchange and cooperation between China and Pakistan. KEYWORDS

Socio-Cultural Exchange; People To People Contact; Bilateral Cooperation, Literature and Art; Social Media; China Pakistan Economic Corridor
\end{abstract}

\section{INTRODUCTION}

"Silk Road" is 2000 years old project that is well known as the "Belt and Road Initiative" (BRI). Impact, Belt and Road Initiative is a Chinese initiative for global development in which included industrial zones, communication infrastructure, the energy infrastructure in Asia, Africa, Europe, Americas, Middle East and international organizations.

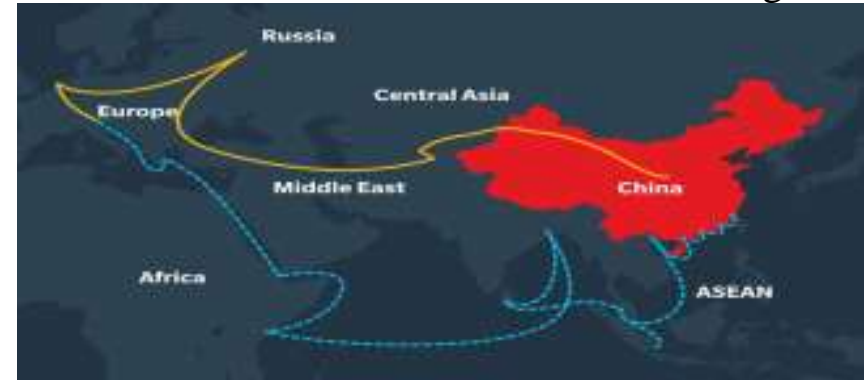

Figure 1. The energy infrastructure in Asia, Africa, Europe, Americas, Middle East and international organizations ${ }^{1}$.

\footnotetext{
${ }^{1}$ Facebook, E. T. T. |, \& About the Author Editorial Team We are experts with the mission to inform. (2019, September 24). The Belt and Road Initiative (BRI) has significant potential to be powered by solar energy. pvbuzz.com. https://pvbuzz.com/belt-and-road-initiative-bri-potential-powered-by-solar-energy/.
} 
Cooperation between China and BRI countries can play a crucial role to complete BRI projects. Thus, this study aims to explore the area of socio-culture exchange and cooperation in this field and its current scenario and future challenges. As Ali \& Geng, (2018) expressed, the cooperation between China and BRI counties can play a vital role in completing every task. So that the cooperation will also play a vital role to bring socio-cultural, exchanges, people contact and introduced different cultures that would be helpful for people to know about other peoples, language, and customs. People will travel in different countries through this road for material exchange and take part in cultural exchange. As well as knowledge about technology, crafts, literature, art, and science shared through BRI countries, cultures and languages will be developed and influenced on each other ${ }^{2}$. China Pakistan Economic Corridor (CPEC) is a critical BRI project that integrates many countries through the CPEC and CPEC project and will play a vital role in making stronger relationships between China and Pakistan. In the beginning CPEC, project value was $\$ 46$ billion and now the current value is $\$ 62$ billion for the development of communication infrastructure, transportation and energy projects. These projects are game-changers for Pakistan (Asif \& Ling, 2019).

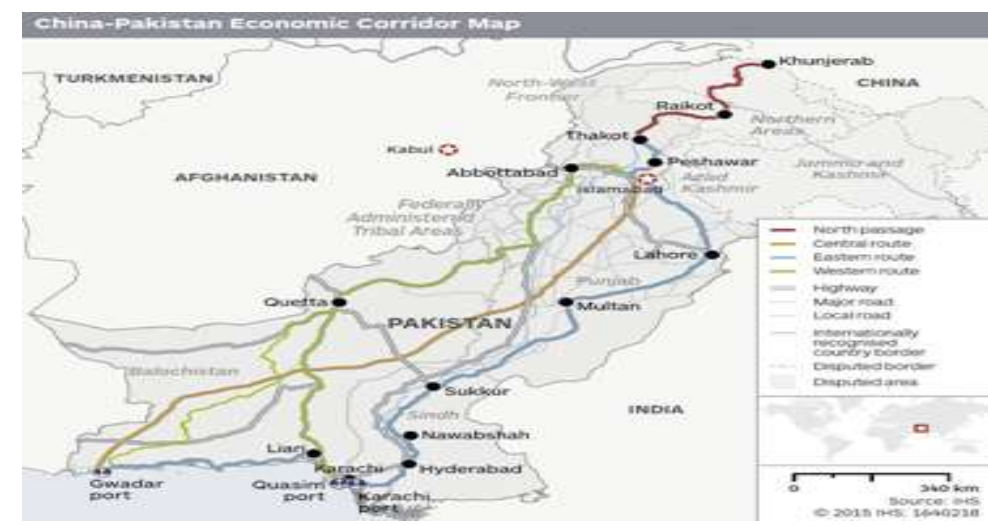

Figure 2. China - Pakistan Economic Corridor Map ${ }^{3}$

Pak-China has long history of cultural communication since the establishment of ancient Silk Road. Cultural exchange and cultural cooperation gradually increased during this time. In spite of growth between China-Pakistan in the field of economic and trade, there is a vital area of cultural cooperation and communication that need to improve from both sides. Under the CPEC project, there is a need to emphasize cultural cooperation and cultural communication in other areas covered in this project. Many fruitful exchanges and cooperation in different fields such as sports, education, Literature, art, cultural relics, information, youth affairs, women affairs, health, publications, archives, and etc. Chinese art troupes visited in various Pakistan cities and performed folk songs, dance, acrobatic, and performed traditional instrumental. President Xi delivered a speech during the 18th Shanghai Cooperation Organization (SCO) and stated that for prosperity and peace-seeking common ground, Because of cultural bonds and people-to-people exchange "Shanghai Spirit" (Asif \& Ling, 2018).

A theoretical research technique has been opted for and gathered the secondary information by exploring the various reliable and authentic resources. The method of analytical study has been used previously by many research scholars (Asif \& Ling, 2019;

\footnotetext{
2 SILK ROADS DIALOUGE, DIVERSITY \& DEVELOPMENT. (n.d.). Retrieved from https://en.unesco.org/silkroad/about-silk-road.

3 Furqan, M. (2018, January 5). CPEC Route - A Complete Guide to CPEC and its Significance. CPECBULLETIN. https://cpecbulletin.com/2018/01/05/cpec-route-a-complete-guide-to-cpec-and-itssignificance/.
} 
Ali, Gen \& Saleem, 2020; \& Ziaur Rahman et al., 2020). Secondary data from Official databases as the Belt and Road Portal, China Pakistan Economic Corridor Portal, Embassy of China in Pakistan, Embassy of Pakistan in China, newspapers, reports, magazines and articles have been used in this research. The study has also consulted various policy papers, journal articles, reports, and working papers of international organizations like UNESCO. The researchers have tried to include very recent data from all possible sources to expedite the argument.

\section{Historical Significance of China-Pakistan Friendship}

Since 1950 Sino-Pak relations started (Arif, 1984) relationships were more improved in 1953 after the trade agreement (Dixit, 1987). Since 1970 both countries relationship became stronger in all sectors. People of two nations build respectable confidence with friendly policies. We can see the upshot of this deep-rooted friendship with great achievement in the China-Pakistan Economic Corridor (CPEC); both countries are significant partners and working together to save their common interest with strategic communication. In 2013 China, reiterates the idea of the Silk Road for regional integration along the BRI Economic Belt to perceive the economic demands of the whole world ${ }^{4}$. CPEC project is a game-changer for Pakistan and an exemplary model of cooperation that has the potential to bring a positive change not only for regional but also for international level and will help to overcome against the backdrops. China's premier Li Keqiang李克强 in May 2013 came to the visit to Pakistan and he quoted with a catchword that "good neighbors are a blessing" and during his visit, he gives particular importance that Pakistan is an "iron friend" and trustworthy for China.

Furthermore, Chinese people are called Pakistani people with a special phrase "Ba Tie 巴 铁” (trustworthy Pakistan and Iron Brother) ${ }^{5}$. Chinese President Xi Jinping in April 2015came to Pakistan, and during this visit of Mr. Xi both sides decided to more improve their relationship in course of all-weather strategic partnership ${ }^{6}$ and both countries signed on fifty-one agreements (Khan, n. d.). Gwadar port is a key part of CPEC project in which industrial zones, communication infrastructure and energy infrastructure (Asif, 2018). This corridor will improve the life of people and boost long-term socio-economic prosperity ${ }^{7}$. Let us have a look on cultural exchanges between both countries; it will be helpful to know about the existing status and framing the future strategy. As stated by the Embassy of the People's Republic of China (PRC) in Islamabad Pakistan, cultural exchanges between two countries links from the antique times. Since 1949 after the founding of the PRC, both countries took a number of steps to enhance the cultural exchange from both sides. From 25 March 1965, the most important step was to promote a two-way exchange in which both countries signed the Cultural Cooperation agreement. Both countries recommenced the signing and execution regularly of a two-year executive program. The outcome of this thing is that cooperation of cultural exchange has made ceaseless progress since the diplomatic ties of both countries. In May 1983 and November 1991 high-level cultural exchanges between both countries and a

\footnotetext{
4 Mahar, A. (2015, April 24). Why Chian's “One Belt, One Road” Initiative matter for Asia. Azernews.www.azernews.az/analysis/80980.html

${ }^{5}$ Xinhuanet. (2013). Chinese premier hopes for more fruits in friendship with Pakistan. Xinhuanet

${ }^{6}$ Lu, A. (2015, April 20). China Pakistan Lift Ties to All-Weather Strategic Partnership of Cooperation. Retrieved from Xinhua News Agency: http://news.xinhua.net/english/2015-04/20/c-134167316.htm

${ }^{7}$ Tiezzi, S. (2016, Feburary 5). Pakistan will provide Special Force to defend Chinese Investments. Retrieved from The Diplomat: http://thediplomat.com/2016/02/pakistan-will-provide-special-force-to-defend-chineseinvestments/
} 
Chinese Government Cultural Delegation visited Pakistan. A Pakistani Government Cultural Delegation visited to China in November 1981, June 1982 and September $1999^{8}$.

Moreover, Beijing and Islamabad held many fruitful exchanges and cooperation in different fields such as sports, education, Literature, art, cultural relics, information, youth affairs, women affairs, health, publications, archives, etc. Chinese art troupes visited in various Pakistan cities and performed folk songs, dance, acrobatic, and performed traditional instrumental. As told by official sources, two-way exchanges occur in different areas like handicraft, painting, over and above puppet show. From both sides, the literature quite a few translated into each other's language throughout the year. In the field of TV and film, a special agreement was signed in the mid-1980s by the governments of both countries to promote the cooperation of several TV programs jointly produced to enhance people-topeople contact ${ }^{9}$. Sino-Pak cooperation in the field of education has been increased over the past years. The Chinese government offers hundreds of scholarships to Pakistani students. Currently, 25,000 students are enrolled in Chinese universities; according to Pakistani education attach in Beijing, around 7,034 are studying on scholarships ${ }^{10}$ and increasing every year.

\section{Literature and Art}

Definitions of literature have varied over time. In Western Europe prior to the eighteenth century, literature as a term indicated all books and writing ${ }^{11}$. A more restricted sense of the term emerged during the Romantic period, in which it began to demarcate "imaginative" literature $^{12}$. Concerning art, the "institutional" definition was first proposed by George Dickie in $1969^{13}$, and again, in somewhat revised form, in his 1974 book Art and the Aesthetic:

"A work of art in the classificatory sense is (1) an artifact (2) a set of the aspects of which has had conferred upon it the status of candidate for appreciation by some person or persons acting on behalf of a certain social institution (the art world)." 14

To understand literature, various ways can be in written or oral works such as drama, poetry, novels in which words use to stimulate the reader's imagination and make available a unique vision of life for the reader. Literature is a creative work, a universal form of expression that is discourse intellectual human's concerns, emotional and spiritual. This notion dated back from the fourteenth century. From eighteenth-century, Literature viewed as sound written books or creative work of an imaginative. Good literature is believed to disclose the creativity that can raise new points of view, debates, and reader expands his understanding by himself and refreshes his spirit. Additionally, literature can have survived

\footnotetext{
${ }^{8}$ Embassy of the People ${ }^{e e}$ s Republic of China in the Islamic Republic of Pakistan, 17 January 2017, accessed on 29 October 2017 (http://pk.chineseembassy.org/eng/cultureservice/t179992.htm).

${ }^{9}$ Ibid.

${ }^{10}$ Pakistan Defence. (2019). Pakistani students studying in China. [online] Available at: https://defence.pk/pdf/threads/pakistani-students-studying-in-china.608537/ [Accessed 20 Sep. 2019].

${ }^{11}$ Leitch et al., The Norton Anthology of Theory and Criticism, 28

${ }^{12}$ Ross, "The Emergence of "Literature": Making and Reading the English Canon in the Eighteenth Century," 406 \& Eagleton, Literary theory: an introduction, 16

${ }^{13}$ Dickie's earliest formulation of an "institutional" definition of art was the following: "A work of art in the descriptive sense is (1) an artifact (2) upon which some society or some subgroup of a society has conferred the status of candidate for appreciation." "Defining Art," American Philosophical Quarterly, 6 (1969): 254

14 Dickie's 1974 definition, quoted by him in Introduction to Aesthetics, 83. Dickie's phrase "status of candidate for appreciation" seems an unnecessarily convoluted way of saying "status of art," which is, presumably, what he meant. The latter phrase would, of course, have rendered his definition even more evidently circular. On the concept "art world," see below, n. 17.
} 
with a large variety of media such as audiovisual, audio, oral, etc. That is a cultural expression for the reason that it expresses the beliefs, human knowledge, and behaviors (Eyong, Mufuaya, \& Foy, 2004).

The word art might talk about to several things such as:

$>$ Study of a creative skill,

$>$ Process of creative skill,

$>$ Product of creative skill

$>$ The audience's experience with the creative skill

Art is a touch that stimulates an individual's ideas through the senses or thoughts, emotions, beliefs. Creative art is a group of disciplines that produce artwork and are compelled by a personal drive and deliver a message and mood. Artworks interpreted based on images or objects or can be openly made for this purpose. According to some scholars like Kant, arts and sciences could be well-known by taking science such as on behalf of the field of knowledge and the arts on behalf of freedom of artistic expression.

\section{Relationship between Literature, Art and Economic}

The relationship between literature, art and economics is complex; in particular, society literature can understand to reflect the economic reality. Marxist argues that literature is not only a reflection in the society but also a specific socio-economic structure. In that particular society, the socio-economic condition of the author may be considered, such as literature being in written form. Literature is an economic activity such as a product to be produced and consumed. In the history of literature various trends and movements in terms of changes in material conditions of rise and decline of a particular genre can be interpreted and subsequent change in economic relations and structures.

In contrast, at a particular time of economic relations and economic structures of society to study the material conditions of literature can be understanding as the source of information. Centuries ago, economic ideas through several kinds of literature were used like both media of broadcasting and challenging, on the contrary, economist borrowed images from literature to give their arguments (Narayan, 2017). Economics is a discipline of culture and society that should be taught with strong reference to society and different human endeavors. There is an important aspect to measure people's feelings (positive or negative effects) like anger, worry and pain or respect, pride and pleasure. Economists measure people's experience through qualitative variables on the other hand, literature portraits these feelings through interwoven characters of the multifaceted web of social, interaction, political, economic and psychological. These images and fiction in portraits enhance the understanding of economists for human well-being (Stiglitz et al. 2009). Literature can "shape public opinion and standards on economic issues" though economic believed "direct drama, literature and language (Watts and Smith 1988). The use of literature, music, and films in economics classes shows there are educators and interesting ways (Becker and Watts 1998).

People need to communicate with each other through different expression, they draw image of their target to keep safe and sound their needs. Music is also valuable and creates new ways for the expression of emotions and communication and people used to express their sadness or joyful moments by laughing or crying. With the passage of time, these kinds of things turn into musical and melody instruction to increase the appreciation of beauty. So the born of economy and art are mainly attentive to the basic needs of human beings. Economics and artistic work in time expanded new dimensions in society, furthermore in civilized societies art became an important part. In an economic system economics concerns about growth, stability and equity, in the same way art plays a harmonising role to attain this 
aim. The creation of artistic work and economy based on real actions and efforts creates nonphysical and physical objects (Alpagu, 2014).

\section{The Time Value of China-Pakistan Economic Corridor}

CPEC project will enhance cooperation between Pak-China in socio-cultural and regional cooperation based on a win-win situation. There is a need to review CPEC projects from socio-cultural perspectives because socio-cultural cooperation can play an important role between two nations for deep understanding of their culture's language, customs, food, literature, and art will also provide a chance for self-reflection. For regional cooperation socio-cultural is a relatively significant place that will boost relationships through cultural cooperation and provide an opportunity to connect peoples of both countries. In society, culture is the way of life that is shred everyone in particular society, that is, take account of technology, buildings, languages, traditions, ideas, customs, etc. While social and culture are closely interlinked and related concepts, can never be detached. Cultural change is a broad term that is the phenomenon of all humans and brings social change and development in society (Ibrar, Mi, \& Rafiq, 2016). CPEC is a mega project and both countries have strong strategic relationships, such as every nation's youth is the nation's power, both countries young generation can play an important role to promote their cultures and enhance the people to people contact via a friendly cultural exchange platform.

The friendly exchange between Pak-China is a model of strong relations. Pakistan announced to promote friendly exchange by the China and Pakistan welcomed to establish Chinese cultural center and some packages announced in CPEC such projects like International Documentary Channel, CCTV English News Channel, China radio international launched Tianlu studio and Pak-China Joint National Research Centre, Smallsized Hydro Power Technology in Pakistan (Khalid, 2015). It is large in amount when we see the influence of CPEC between two countries about cultural exchange. Since few decades the world has been viewed the power of culture, cinema has the power to bring close the culture, people and nations. Pakistan and China both countries have realized the significance of the entertainment industry to make more strong cultural ties in the future in the field of television, film, artistic work exchange between two nations will make more useful to bring closer of each other ${ }^{15}$. Culture refers to the groups within a society or ways of life that consist of how people dressed, marriage, language, customs, family life, religious ceremonies, and their patterns of work. Between both countries, cultural relations are comprehensive and more neutral. Particularly it has been true underneath $\mathrm{Mr}$. Xi especially mark a turn for the better of the Silk Road cultural exchange is a new momentum between the "Iron Brothers". In May 2017, Beijing held Belt and Road Summit, which emphasized promoting contacts between people, cultural exchange, and mutual understanding. In material culture, Pak-China exchanging material and non-material culture in material culture exchanging commodities, products, and resources. Non-material culture consists on living patterns, dress, food, religion and language. Pakistan is actively taking part in various kinds of cultural activities, the director of the Pakistan National Council of Arts (PNCA), came for a visit to China in Xinjiang province with their delegation and performed therein cultural festival. Cultural activities between both countries are increasing gradually like a storm. Pakistani students studying in China are making great progress and carrying their cultural

15 China Daily (2019). CPEC: A way forward to strengthen cultural ties. [online] Available at: http://www.chinadaily.com.cn/a/201901/22/WS5c46d167a3106c65c34e5da5.html [Accessed 20 Sep. 2019].

${ }^{15}$ Daily Times (2019). CPEC is a key to cultural relations between China and Pakistan. [online] Available at: https://dailytimes.com.pk/369142/cpec-is-a-key-to-cultural-relations-between-china-and-pakistan/ [Accessed 20 Sep. 2019]. 
pattern, norms, values and traits, and every year Pakistani students present their culture on cultural days. In China, everyone knows about China-Pakistan friendship and called (巴铁 batie) iron brother or (好朋友haopengyou) meaning good friends. Food has great importance between cultural and people relations, Chinese people who live in Pakistan they like Pakistani food and spices. In Pakistan, there are a number of Chinese restaurants in Karachi, Islamabad, and Lahore, in these restaurants have the same taste food as in China. In China Pakistani food are also available in big cities, another CPEC effect is that Pakistani and Chinese are marrying with each other, most of live in China. Many Chinese are working in CPEC projects and them marrying with Pakistani women and live in Pakistan. Between China and Pakistan, this is a new bond cultural wave taking place in both countries and beginning between two diverse cultures. Chinese language has created many job opportunities in Pakistan and getting a strong attention in academic courses of Pakistan ${ }^{16}$. Between China and Pakistan have signed cultural agreement to promote cultural relations, on behalf of their respective countries from both states Minister for information, Literary Heritage and Broadcasting signed the agreement. Senior officials and ambassadors of Pakistan to China were also present there; this agreement consisted of cooperation in Education and Research, Broadcasting and Films, Press and Publication, Youth and Miscellaneous, Culture and Art, Sports. To enhance the cooperation between Pak-China organizations of both countries in the technology field of television, film, and radio broadcasting. Both sides in the field of culture and arts will encourage the artists in which art galleries, archival institutes and cultural relics, theatres, archival institutes, and restoration of labs are also part of this agreement. Pakistani folk arts, crafts and Lok Virsa held in China based on cooperation. This exhibition's main purpose is to introduce Pakistan's status quo of cultural heritage and folklife through videos, photos, and audios to the Chinese. The vision of President Xi Jinping is a historic moment that is not only for BRI countries but also for the whole world, on both countries, there is a greater responsibility for implementation of the process. Mr. Xi stressed on cultural exchanges by way of the fourth core piece of the BRI during the 19th Congress of the China Communist Party (CPC). The relationship between Pakistan and China has been implanted into our culture, in 2017 from Xinjiang to Gwadar organized CPEC Cultural Caravan. In CPEC Cultural Caravan, Chinese visual artists also participated and performed arts and Pakistan Ministry of culture proposed to establish FM Radio along the CPEC route. The Chinese Minister of Culture welcomed the Pakistani delegation and stated that after the visit of Mr. Xi to Pakistan in 2015, both countries shared progressive and enrich cultural relations. He said the CPEC project is not only for economic and trade. It will promote cultural exchange between two countries. He further stated that in less than a year, different types of 38 events were introduced in Pakistan, including performing arts and exhibitions. Both countries Ministers of culture talk about the plan in affections to creating Pak-China Cultural Sister College and University, Pak-China National Cultural Centre and Cultural Film Academy. During their talk, they discussed the introduction of Pakistani movies in Chinese cinemas. The Minister of State stated that regarding CPEC Pakistani media is creating awareness among people, and print media contribute numerous articles and editorials even though Expo at Gwadar was live telecast by Pakistani news channels ${ }^{17}$.

\footnotetext{
${ }^{16}$ Daily Times (2019). CPEC is a key to cultural relations between China and Pakistan. [online] Available at: https://dailytimes.com.pk/369142/cpec-is-a-key-to-cultural-relations-between-china-and-pakistan/ [Accessed 20 Sep. 2019].

${ }^{17}$ Pakistan, China sign cultural agreement. (2019). [online] Available at: https://nation.com.pk/07-Feb2018/pakistan-china-sign-cultural-agreement [Accessed 20 Sep. 2019].
} 
Between both countries artist of Pakistan calls out to further cooperation and have confidence in that cultural exchange will open a new chapter for the two sides. The managing director of Pakistan National Council of Arts stated that it is a great opportunity for Pakistan to learn from China because China has rich cultural infrastructure. He further stated, "In numerous culture areas, there are various opportunities for exchange, including theatre, music, dance, archaeology, cinema, history, etc. Cultural agreement between both countries will open up opportunities". Pakistani filmmaker Syed Noor stated that Pakistan's film industry is on revival phase and a good friend can come for its rescue in this hour of need. Further Noor told Xinhua news that China again has proved brother country always stands with Pakistan's side in any field of life, he was happy that both countries will work together in the cultural field. China uses modern technology for filmmaking and china also has enormous in film industry, and cultural cooperation program is an opportunity for Pakistani people to learn from Chinese. He said he is very glad to watch Chinese vice versa films screening in Pakistani cinemas. Theatre artists are also with cultural exchange agreement between Pak-China it is an opportunity that Pakistani theatre actors can learn from the Chinese artist. An educationist Attiya Saleem, in Islamabad stated that Pakistanis like to watch Indian movies and dramas but with the entry of Chinese dramas, movies it would be a great impact on Pakistan cultural scene and movies and dramas has great influence in society and nations to know each other's and variety of cultures ${ }^{18}$. This year Spring Festival, Chinese Lunar New Year and multiple cultural performances was organized in Pakistan's different cities to celebrate the event. This is a new cultural phenomenon and an indication of Pakistan's rising suitability over Chinese culture. Thousands of Pakistanis were participated during this event various cultural activities were organized in Pakistan such as Chinese calligraphy, use of chopsticks, Chinese painting, paper cutting and dumplings that is propitious sign of Chinese traditional New Year food. The Minister of Foreign Affairs of Pakistan said it has been more visible that in every aspect of life-extending cultural acceptability between both countries in field of food, language and literature. The Cultural and Education, Foundation of Arts and event organiser, Mehnaz Perveen, stated that Pakistani government inspiring Chinese dramas with Urdu translation to be telecasted in Pakistan and the process of broadcasting has already been started Chinese dramas on Pakistani TV channels. Chinese art groups are visiting in different cities of Pakistan and performed folk songs, dances, Chinese art groups have made regular visits to numerous Pakistani cities and performed traditional dances, folk songs and Chinese music that is common among the Pakistani public. She further adding that a great turnover can observed and self-evident truth for Chinese cultural shows that Pakistani people respect and love Chinese culture ${ }^{19}$.

\section{General Situation of Cultural and Artistic Exchanges between China and Pakistan}

The natures of trade and people-to-people relation have become powerful between China and Pakistan. A Cultural exchange between the China and Pakistan is now overwhelming through the effect of CPEC. In the last few years, the world has observed the power of culture. Newly in China, the first Pakistani movie release "The Legend of Maula Jatt".

\footnotetext{
${ }^{18}$ Xinhuanet.com. (2018). Spotlight: Pakistani artists welcome cultural agreement between Pakistan, China Xinhua | English.news.cn. [online] Available at: http://www.xinhuanet.com/english/201802/16/c_136979433.htm [Accessed 20 Sep. 2019].

${ }^{19}$ Xinhuanet.com. (2019). Feature: China-Pakistan relations thrive on cultural frontiers with rising trend of mutual acceptability - Xinhua | English.news.cn. [online] Available at: http://www.xinhuanet.com/english/2019-02/05/c_137800460.htm [Accessed 20 Sep. 2019].
} 
Cinema brings people, culture and even nations closer by providing a common platform and eliminating all discriminatory hurdles. Significant importance of entertainment industry has realized by China and Pakistan to power the cultural ties. In future, the bond between the two countries will be more potent by television and film exchange. In last few years, after the initiative of CPEC, there had been some significant effects of China-Pakistan relations on the entertainment industry. A Chinese actor plays a guide role in Pakistani movie "Chalay Thay Saath" 20 .

The Minister of state for broadcasting, information, national and literary heritage and Chinese corresponding person conferred the agreement between Pakistan and China to coproduce film. In the area of film infrastructure and film production CPEC association will be venturing while talking about the association between Television and Radio of ChinaPakistan, Pakistani Government is working on a film which will quickly be made public to incentivise and stimulate the film industry in Pakistan. China and Pakistan could modernise and promote their industries equally as Pakistan was now creating better quality film for cinema by following the Chinese model and taking pride in the modern pitch of films produced in Pakistan. The minister of state for information, transmitting and literary heritage and Chinese fellow was talk about the agreement between the both countries to co-produce films in $2018^{21}$.

The forthcoming movie to be mutually created by Pakistan with its mutual friend China will focal point on international trade cooperation under the China-Pakistan Economic Corridor (CPEC), of the Belt and Road Initiative (BRI the movie "The Journey, is all the more related because Pakistani and Chinese closer than ever before through CPEC. Wang Haipang, known as director of script writing committee of China Television Artists Association, suggested that film will highlight the close friendship of people from the two countries and will be based on genuine life stories. Pakistan contributed at the newly concluded Silk Road International Film Festival (SRIFF), for the first time with the film named as "Teefa in Trouble." In a Conference managed by Miao Xiaotian, president of China film co-production, Ali Zafar, famous as producer of the film, pitched for expanding mutual film cooperation. An executive programme of the Cultural Agreement for 2018-2022 was signed during a meeting between China's Minister of Tourism and Cultural and Pakistan's Minister of Broadcasting and Information in February this year, which grasp the enormous potential for bridging language and cultural hurdles. Separately from Government-to-Government contacts, the people of Pakistan and China share general values that are inserted deeply into their customs. Mutual respect, powerful familial string and close adherence to traditions are developed from their cultures. They will be capable of gaining from each other's cultures, appreciating one another, and powerful their bond of mutual friendship through film that has surpassed all history challenges. Many economic opening with China have become accessible for Pakistani's through the launch of CPEC. As an outcome, bureaucrat-learning excitement in Pakistan is in total swing. Opportunities for Chinese film producers recommend by this growing mandarin audience that can be consumed not only for increasing ties but also for industrial purposes.

A similar is right for Pakistan filmmakers that are planning to construct on the wide Chinese film market. Urdu movies dubbed in Chinese language are bound to be successful

20 China Daily (2019). CPEC: A way forward to strengthen cultural ties. [online] Available at: http://www.chinadaily.com.cn/a/201901/22/WS5c46d167a3106c65c34e5da5.html [Accessed 20 Sep. 2019].

${ }^{21}$ The Express Tribune (2018). Pak-China agreement to collaborate in film production. [online] Available at: https://tribune.com.pk/story/1627466/4-pak-china-agreement-collaborate-film-production/ [Accessed 20 Sep. 2019]. 
by considering the historical attraction of Chinese people for Pakistan. Enhancing profits for China will ensure industrial growth for Pakistani film producer and eventually enhance yield qualities. A way forward is to assume multi-lateral contribution. Foremost cultural and film authorities of he both countries should be close collaboration. Continued association among China's Film Group Corporation and Pakistan's Ministry of Information and Broadcasting will certify that both are on similar edge when launching mutual projects and facilitate private investors. $^{22}$

Wang Haiping, dramatist of "Tian Lu, （天路）" or "The Way of Haven", told that "Tian Lu" is a film based on actual events and real people and he is also the director of Chinese TV Artist Association's scriptwriting committee. It loyally evidences of the Chinese project response to the "Belt and Road" initiative and allocates with Pakistan. It is constructing a China-Pakistan Economic Corridor, a joint helpful and win-win situation, enhancing the prosperity and development of the state, admiring the Pakistani and Chinese entrepreneurs and social campaigner who have made significant collaborations to the friendship among China and Pakistan, revealing the joint help among Chinese and Pakistani people. According to Wang Haiping, China and Pakistan will cooperate in the entire procedure of filming, creation, screening, post-production and distribution of Tianlu. The two sides have begun to assist in the collection and creation of wind at present. It was ensured to start shooting in early 2019, mainly in China's Xinjiang, Pakistan and the West Coast New District of Qingdao. In current years, Qingdao West Coast New District has construct Television Cultural Industry Zone, Qingdao Ling shan Bay film and has built a new television and film industry cluster like film and television production, film and television investment and cinema management. According to the journalism and cultural officer of the Pakistani legation in China, Henna Foldos, desired that "Tianlu" could be fruitfully accomplished and became a mould for television and film culture cooperation among China and Pakistan ${ }^{23}$.

In 2017 on PTV, a Chinese TV series will first appear in Pakistan, a 36-episode television series known as Beijing Youth on-air. Newly, a consensus is signed to broadcast the serial on PTV by the state television of Pakistan and China Radio International. According to this agreement, international networks composed Beijing Youth, a 36 set of Urdu language TV series, will be circulated in Pakistan state television on the evening time from early November. A Chinese ambassador said that $70^{\text {th }}$ anniversary of Pakistan will also contribute by the Beijing Youth. Translation of series highly praised by Ahmed which is the deputy director of Pakistan state television station. He said, "Quality of sound is good, translation the drama is in place, actors in play are well able and we can concentrate on recent China's culture." Animated series and movies have been translated from Chinese to Urdu by the Chinese and Pakistani governments under the Belt and Road Plan. In recent years, Chinese movies and television programs in many languages are translating and telecasting by China Radio international that has progressed quickly as per a website ${ }^{24}$. Chinese opera animated cartoon series known as "Three Drops of Blood" will be broadcast by Pakistan Television (PTV) on its Urdu channel PTV-world and local media reported on Saturday. Hassan Immad Muhammadi, the PTV managing director, says that in six parts of the episode, the series would be telecast every Saturday on PTV world starting from May 18, 2019. He believed that Three Drops of Blood would fascinate many viewers across Pakistan and abroad as it is

\footnotetext{
${ }^{22}$ News Network (2018). Silk Road Film Fest poses more Pakistan-China film collaboration. [online] Available at: https://gnnhd.tv/index.php/Entertainment/2739-1541358 [Accessed 20 Sep. 2019].

${ }^{23}$ Xinhuanet.com. (2019). 中国和巴基斯坦将合拍电影《天路》-新华网. [online] Available at: http://www.xinhuanet.com/world/2018-06/14/c_1122987753.htm [Accessed 20 Sep. 2019].

${ }^{24}$ PTV to telecast Urdu-dubbed Chinese drama - CPEC. (2017, November 20). Retrieved September 20, 2019, from http://pakchina.pk/ptv-telecast-urdu-dubbed-chinese-drama/
} 
a significant addition in the list of programs shown on PTV. On Friday evening, some short clips of animated serial were watched at the Pakistan National Council of Arts (PNCA), on this incident, PNCA director Jamal Shah said that the series illuminates the resemblance between the both countries and he acclaimed the cultural exchange between the China and Pakistan. According to series director named as Bai Zhijun, "The colours of the series are glorious and lively. It transforms facial marks and costumes in traditional opera into cartoon images with a notable personality that attracts the audience." One of the classical master pieces of China known as "Three Drops of Blood" was accomplished in 1918 and its manuscript has obtained from Yuewi Cottage Notes, Ji Yun, a scholar of Imperial Academy and a famous Qing Dynasty classical Chinese novel written by him $^{25}$.

People-people relations have become strong through the nature of the exchange between China and Pakistan. The effect of CPEC on cultural exchanges among both countries is now overwhelming. A Chinese TV series such as the Beijing Youth and Shan food commercial with a Chinese couple on Pakistan Television (PTV) are significant examples. Pakistani advertisement Shan Biryani Masala TVC 2017, this commercial is famous in Pakistan but has the potential to reach people's hearts because various Chinese people also screened it. Films and Television exchange would facilitate the people of China and Pakistan to appreciate each other's values and culture. The Chinese agent managed two festivals on $19^{\text {th }}$ April 2018 at the Pakistan National Council of the Art (PNCA) to celebrate the $3^{\text {rd }}$ Anniversary of the China Cultural Centre in Pakistan. A mutual exhibition of Chinese and Pakistani conventional artists was occurring in cooperation with COMSATS Art Gallery. Mr. You Yi, the Cultural counselor of Chinese Embassy, Dr. Raheela Qamar, Rector COMSATS and Mr. Yao Jing, Ambassador of China to Pakistan, attended ceremony. Aim of the ceremony is to bring the two countries closer and permitting them to understand the conventional art of each other's, said by the curator, Farah Mahmoud. Works of famous artists such as Ahmed Habib, Aqeel Solangi and Amna Hashmi are among those exhibitions. Some traditional features of Chinese Opera like woodcut prints by Chinese Artists are another fascinating medium on display. Chinese ink wash painting boosts the whole wall and mediums like miniature, calligraphy, oil printing, and printmaking are on exhibition and persisted until $7^{\text {th }}$ May. The Baoji Art Theatre group managed a performance named as 'Impression of Tang Dynasty-New Silk Road Spirit' in the main hall of PNCA, brought to Pakistani by the Shaanxi Provincial Government of Culture. The Pakistan Minister of State for Information Broadcasting and Literary Heritage was the chief organizer.

Some Pakistani efficiency to the program included by the PNCA Company, initiating with a Sindhi dance on 'Laal Meri Pat.' Punjabi Bhangra and Pushtun Khattak dance were also furnished on this exhibition. Next, a male singer from Shaanxi, Yuan Shuai, performed a farewell song 'The Lament of Separation', devoted by the singer to his dearly loved and his other song was far more optimistic which named as 'Men of Guan Zhong'. Next, Madam Hu Ge sang 'The Song of Zhen Guen,' which describes the fluctuation of the Tang Dynasty, focal point on the spirit of harmony which reigned during this era. For one last presentation, the whole Baoji Art Theatre group took to the stage finally. The performers invite farewell with 'Shaanxi Drum Dance' by dancing on beating drums. Seminars on Chinese medicine, clothing and art display, Tai Chai and Ink-Wash painting classes such as the Rhythm of Liaohai Gala arranged by the Chinese Cultural Centre play a vital role in introducing many aspects of Chinese Culture for Pakistanis ${ }^{26}$.

${ }^{25}$ CGTN (2019). Pakistan Television to telecast Chinese folk opera cartoon series. [online] Available at: https://news.cgtn.com/news/3d3d674d77637a4e34457a6333566d54/index.html [Accessed 20 Sep. 2019].

26 (2018, April 26). The 3rd Anniversary of China Cultural Centre in Pakistan. doi: https://www.youlinmagazine.com/story/3rd-anniversary-of-china-cultural-centre-in-pakistan/MTEwMA== 


\section{Enhancing Culture Communication through Radio}

At Broadcasting House in Lahore, China radio international in cooperation with radio Pakistan has started Dosti Channel FM-98. An interesting and fascinating ceremony listened by Dingbin, the Chinese Consul General in Lahore, Director News and Current Affairs, Station Director Islamabad and Lahore, Director General Radio Pakistan, Director Programme and Chinese officials. Dosti channel termed as a milestone in China-Pakistan friendship by the Chinese Consul General on this ceremony. He stated that bilateral ties of both countries become powerful and vigour in modern era due to China-Pakistan Economic Corridor. According to Director General Radio Pakistan, Dosti Channel will further power the many aspects of bilateral relations. FM-98, Dosti Channel firstly instigated in Islamabad on $19^{\text {th }}$ December 2016 by China Radio International (CRI) and Radio Pakistan after an accord among the both Governments. After this, another FM channel was initiated in Karachi. China-Pakistan mutual project among the broadcasting organizations is intended to promote contact between people to new heights and enhance radio collaboration between both countries. Daily six hours of Urdu programmes for Pakistani viewers provided by Dosti Channel. From Kashghar to Gwadar, initiate a CPEC radio channel raising scope are planning by the Radio Pakistan and China Radio International ${ }^{27}$. One of the main obstacles to intercultural communication is the lack of a shared and preeminent language and culture. Therefore, radio broadcasting can play a vital role, in order to be able to establish a progressively enlightened understanding, aware of the cultures of others, it would be important or even necessary to resort to the acquisition of knowledge. The desire to have recourse to the mastery of a few languages that are different from ours to be on the same level with others can prove essential. Knowing, even if only a little, about cultures and traditions that are different from our own can be a factor that can help us identify this complicated and exceptional network of influences that have shaped the citizens of each culture (M'Begniga, \& Asif, 2020).

\section{The Role of the Social Media In Improving Contacts Between People}

Strong communication and friendship will develop by the media in China-Pakistan through frequent contact and communication between the people, facilitating us in many aspects. Media will facilitate us to conclude a good change in a speedy global world and flourishing Pak-China relations to grow better. Pakistani and Chinese media reflect the 'aspiration for deeper ties' demonstrated by the official statements. Media plays an important role in constructing and sustaining a good image of Pak-Sino ties and both governments have engaged the media. Moreover, an important example of closer cooperation to mutually tackle 'Western media propaganda' which is debating by Beijing Review to inaugurate a media University in Pakistan with Chinese collaboration (Hameed, 2016). This is reflection of the generally held idea in two countries that they are misperceived victims of Western press coverage.

In Islamabad, at least in official clusters the Pak-China Institute and its publications such as Nihao-Salam and Youlin, which facilitate maintaining the image of a closer relationship? Examples of modern initiatives taken to promote people to people relations are the establishing of a Pakistan-China Media Alliance, a followers Institute in Pakistan, ChinaPakistan Media Centre and China Radio International's server of a daily Urdu service as much as many other blogs, cultural and educational exchanges (Chen, Banerja, Toor \&

27 Cpec. (2017, October 17). China-Pakistan: Dosti Channel FM-98 launched. Retrieved from http://www.cpecinfo.com/news/china-pakistan-dosti-channel-fm-98-launched/NDIyMg== 
Dowine, 2014). It is intimated that different media houses are taking on board in two countries by arranging various workshops and seminars.

Social media is the most important tool to boost up people-to-people communication. Applications in Chinese social media such as WeChat and QQ are more satisfactory and adequate for people as it provides two languages support in each application such as Chinese to English translation and vice versa. Therefore, it is very significant to organize the social media application according to state policy. Different social media apps around the world such as WhatsApp, twitter, viber, Facebook, IMO and Instagram can be advanced among the masses to obtain high output from its usage by making absolute policies to minimize the different hurdle (SIYAL, 2017).

A good image of the two countries civilization, art, language and tourism draws by the print media such as upgrading newspapers and magazines. In boundary areas of China and Pakistan, a newspaper is earlier being printed which is step of enhancing two-way association in cultural fields bilingual that is Urdu and Chinese. Printing different kinds of journals, magazines, and newspapers in bilingual will energize information sharing and improve people-to-people relations.

\section{Ways of Improving Bilateral Cooperation in Cultural Fields}

CPEC is the "flagship" project out of six corridors that improved under the BRI. Sino-Pak affiliations under this project are confident to take a measure jump in trade, political, economic and strategic competitions. It is vitally significant at this point; those two sides take specific measures to improve cultural trade. It will allow the people of both countries to further derive each other's delicacy, culture, important facets of society and facilitate the growth of the bilateral relationship. Three primary methods proposed by this study to further improve China-Pakistan collaborations and cultural trade. Firstly, it is significant to construct an impressive mechanism of cultural trade between the two countries. At the nongovernmental level, exchanges and collaborations are unable to contact all sections of society effectually. China-Pakistan present running mechanism is mostly captured to an official level among the both countries. Government should play an important role in modern mechanism due to its key role in two-sided cultural communication and collaboration. Therefore, various government organizations should still be selected the couriers and leaders of this mechanism like local and national cultural sectors.

Furthermore, resources are provided by this mechanism to make plans for cooperative projects. Under this mechanism, some new organizations must be settled to solve the problems in the application of different projects, checking the efficiencies of projects and being responsible for establishing the target of bilateral cultural exchange. Quality and quantity of cultural exchanges in China-Pakistan are relatively less that is not able to match all-weather friendship between the both countries. According to an ancient Chinese who suggested that joint understanding and contacts between both countries are basis on closer communication. Therefore, it is necessary that under BRI when there are large opportunities then spread the participators in the bilateral cooperation and cultural communication. The participants can be consisting of genius people from educational institutions, culture, media, museum, television and films, tourism and should be involve the popular artist and cultural celebrities. Cooperation between both countries should be promoted by participation of all of them in bilateral cultural communication. In this case, both nations could promote their relations in similar industries. In this way, different social groups can enhance two sided cultural exchanges at different levels.

China-Pakistan Cultural and Art Corridor (CPCAC) can be construct by following the structure of CPEC which improve more bilateral frequent cultural exchange activities 
involving poetry, song, arts and crafts, dance, painting and fine art. Furthermore, the joint exports of cultural products will be promoted by this "CPCAC," which designs more opportunities for other countries through the "Belt and Road Initiative". Another impressive method is developing communication between the people of both nations, particularly for the youth generation. Some efforts should be made to support more Pakistanis to learn Chinese and more Chinese to study Urdu and then accelerate more exchange projects for scholars and students and many culture-sharing circles to ease the businessmen to conclude the difference among the business culture of both countries. Pakistan and China must invest in the build-up of human resources, making it a great task to advantage the bilateral cooperation and CPEC. In the world's industrial development, cultural industry has become an emerging industry and it is one of the most effective and powerful areas in the $21^{\text {st }}$ century, and more countries are utilizing it as a necessary part of their economic growth. Furthermore, people's consumption structure will change from material consumption to cultural production when the per capita GDP is enhanced, which signifies the experiences of developed and Western countries. As the world's powerful economy, the United State of America has the world's biggest entertainment industry and media, making up a third of the whole global market. Television, music and movies produced in US are used worldwide ${ }^{28}$. Similarly, many opportunities are produced by the BRI for cultural industry's progress for the nations. In cultural industry, some feasible regions that Pak-China bilateral collaboration could emphasize on the show as below:

Advertising and publishing industry, festival display, radio and television industry, sports industry, arts and crafts industry, entertainment industry, cultural education, cultural agricultural tourism, cultural apparatus's manufacturing industry, cultural museum network and emerging cultural industry by operating digital technology. Its augury well that both governments are setting up fibre optic, increasing digital connectivity between the both nations under the extended procedure for the CPEC. TV programmes will also introduce under this plan to enhance cultural trade between the both sides. Bilateral cultural exchanges should be further powered by conduct the research and assigning more funds. Actually, there are large numbers of resemblances between the both countries. For example, Khewra's Salt Mine is the second largest mine in the world which is located in Jhelum District and a small city in Sichuan province known as Zigong is also famous for salt mines. Zigong has large networks of expertise researching salt. Therefore, both cities can promote mutual projects and this model can be implemented in other general fields of research ${ }^{19}$. The activity and frequency of China-Pakistan bilateral communication and cultural trade will be fruitfully promoted if the above ideas are accurate. However, it is also feasible to construct cooperation institutes and cultural trade centre such as "China-Pakistan Folk Culture and Art Centre", China-Pakistan Film Centre, which can be fabulous examples of the countries along the "Belt and Road Initiative".

\section{RESULTS AND DISCUSSION}

Firstly, a big "Linguistic Difference" difference has been founded in socio-cultural exchange and cooperation, which could also be considered a great challenge in socio-cultural exchange and cooperation. On sites of CPEC project where many workers and companies have been involved and two potential languages can be used namely Chinese and Urdu. At the beginning, one of the languages is not spoken by one of the parties and vice versa. This language barrier poses huge problems at the start of the project where there is a lot of work

\footnotetext{
${ }^{28}$ Haynie D, "These Are the World"s Most Influential Countries: The U.S. and Russia are the most influential nations, a survey finds", USNEWS, viewed on 28 October 2017, <https://www.usnews.com/news/bestcountries/best-international-influence/>.
} 
to be done. This is one of the realities when two different cultures meet, especially when talking about cross-culture communication. Secondly the "Cultural Diversity" is also vital gap and challenge in socio-cultural exchange and cooperation. This concept of cultural diversity which refers to "multiculturalism" is all the more topical within the framework of the CPEC project since it is important and necessary to talk about it in this part of our thesis which is dedicated to cross- communication culture. Indeed, two different cultures, namely Chinese and Pakistani, meet and must coexist in a specific context created by the CPEC project. Lastly the "Social Aspect", because the phenomenon of social identity is a reality specific to any individual or any social group insofar as there is always the desire to highlight this differentiation with the external group. The attitude tending to highlight social identity generally appears whenever two different social groups face each other. In this specific context, a visiting social group (Chinese workers) and a local social group (Pakistanis) can also call the host country. This social identity can be shown by all the groups that come into contact. However, tolerance can play a big role in mitigating the side effects that may arise. Moreover, there should be programs to enhance different skills that could help communicate, social awareness, language propagation, culture, and art. Social media must tackle the reasons and barriers related to the people's unawareness and formulate the strategies and parameters to solve the communication barriers.

\section{CONCLUSION}

Chinese culture is a spiritual lifeline of the Chinese nation as well as an important source of core values of socialism, and a solid foundation to take a firm foothold in the world culture. China is to inherit and carry forward the excellent traditional Chinese culture and the Chinese aesthetic spirit in combination with the new era conditions. BRI provides new opportunities for Chinese culture to go to the world. We should stick to cultural confidence, highlight the advantages of ourselves, and also have the "other" dimension, and achieve unified coordination. Through mutual understanding between Sino-Pak, we will accelerate in-depth cooperation with countries in the region, provide a broader platform for Chinese culture to spread in Pakistan and also to the world, deepen the world's understanding of China, and enhance the international influence of Chinese culture. With further cooperation in the CPEC being implemented and more desirable needs for regional development are pursued, it is a right time for China and Pakistan to promote more and deeper cultural exchanges and cooperation. These cultural exchanges and cooperation will significantly boost the comprehensive bilateral relationships and help balance the regional developments to deepen further the "all-weather" bilateral strategic and cooperative partnerships between China and Pakistan. The most effective purpose of this project is to achieve understanding and cooperation between national societies for their mutual benefit. Chinese and Pakistanis are exchanging socio-economic patterns to promote mutual understanding, exchanging both material and non-material culture. The activity and frequency of China-Pakistan bilateral communication and cultural trade will be fruitfully promoted if the above ideas are accurate. However, it is also feasible to construct cooperation institutes and cultural trade centers such as "China-Pakistan Folk Culture and Art Centre", China-Pakistan Film Centre, which can be fabulous examples of the countries and the "Belt and Road Initiative". Effect of CPEC on cultural exchanges between both countries is now overwhelming. A Chinese TV series such as broadcast of Beijing Youth and Shan food commercial with a Chinese couple on Pakistan Television (PTV) are some major examples. Between China-Pakistan despite growth in trade and economic growth, there is much needed to improve cultural exchange, cooperation, and communication between both sides. 


\section{Recommendation}

1) Communication Effect of China Radio International and Chinese Teleplay in Pakistan

2) Effect of Chinese Painting Art in Pakistan

3) Dissemination Effect of Chinese Films and coproduction in Pakistan

4) Dissemination Effect of Chinese Opera Art in Pakistan

5) The Ways of Overcoming Misunderstanding in Cross-Cultural Communication

\section{ACKNOWLEDGEMENT}

Authors want to thank the reviewers of this manuscript for their valuable comments, which greatly improve the quality of the manuscript.

\section{REFERENCES}

Anderson, C. A., Gentile, D. A., \& Buckley, K. E. (2007). Violent video game effects on children and adolescents: Theory, research and public policy. http://dx.doi.org/10.1093/acprof:oso/9780195309836.001.0001

Ali, M. and Geng, L.L., (2018). Legal Cooperation in Perspective of Belt and Road Initiative and China Pakistan Economic Corridor.

Ali, M., Gen, L. L., \& Saleem, U. (2020). China Pakistan Economic Corridor: Intellectual Property Rights Importance \& Protection for Small and Medium Enterprises (SMEs). GIS Business, Vol-15-Issue-4-April-2020, 1043-1057.

Asif, M. and Ling, Y.B., (2019). China Pakistan Economic Corridor (CPEC): International Media Reporting and Legal Validity of Gilgit-Baltistan. Asian Social Science, 15(2). URL: https://doi.org/10.5539/ass.v15n2p177

Asif, M. and Ling, Y.B., (2018). Belt and Road Initiative: A Spirit of Chinese Cultural Thought. International Journal of Business and Management, 13(12). URL: https://doi.org/10.5539/ijbm.v13n12p9

Arif, K. ed., (1984). China Pakistan Relations, 1947-1980. Vanguard Books.

Dixit, A., (1987). Sino-Paki Relations and Their Implications for India. Strategic Analysis, 11(9), pp.1067-1080.

Asif, M., (2018). China-Pakistan Economic Corridor: Security Concern and Role of Gwadar Port Prospect for Regional Integration. International Journal of Research.

Eyong, C.T., Mufuaya, M. and Foy, I.I., (2004). Literature and Culture-The sustainability connection from an African perspective. Regional Sustainable Development Review: Africa, pp.1-13.

Narayan, L., (2017). Literature and Economics-Connections and Leverages. Asian Journal of Research in Social Sciences and Humanities, 7(8), pp.357-367.

Becker, W. and Watts, M., (1998). Teaching economics to undergraduates. Edward Elgar Publishing.

Alpagu, H. (2014). Economy and Art: Why are Economy and Art Closely Linked?. Journal of Economics Library, 1(1), pp.3-8.

Hameed, H. (2016). Pakistans Print Media Presentation of Pakistan China Relation and New Silk Route Corridor Project (A Case Study of Chinese President Xi JinPing Visit Days). Journal of Political Sciences \& Public Affairs.

Chen, X., Banerjee, P., Toor, G.I. and Downie, N. (2014). China and south Asia: contention and cooperation between giant neighbours.

M'Begniga, A., \& Asif, M. (2020). The Ways of Overcoming Misunderstanding in Intercultural Communication: An Overview on the Case of China and Mali. 
Ziaur Rahman, M., Sony, M., Shakhawat Hossen Rubel, M., Alam, M., \& Akther Liza, R. (2020). Steps toward Smooth Graduation of Bangladesh from Least Development Countries. Journal of Contemporary Research in Social Sciences, 2(3), 57-67. https://doi.org/10.33094/26410249.2020.23.57.67

SIYAL, S., (2017). Administrative policies of improving people to people contact: PakistanChina strengthening strategic friendship. 